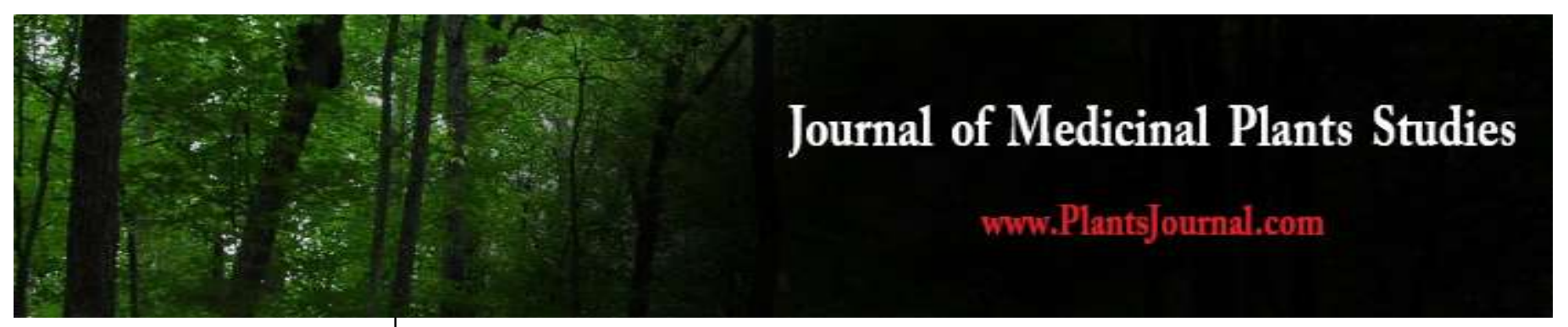

ISSN (E): 2320-3862 ISSN (P): 2394-0530

NAAS Rating: 3.53 www.plantsjournal.com JMPS 2020; 8(6): 55-59 (C) 2020 JMPS

Received: 24-09-2020

Accepted: 27-10-2020

Ginalyn S Pasamonte Master Teacher I of San Mateo Vocational and Industrial High School, San Andres, San Mateo, Isabela, Philippines
Corresponding Author: Ginalyn S Pasamonte Master Teacher I of San Mateo Vocational and Industrial High School, San Andres, San Mateo, Isabela, Philippines

\section{Carbon sequestration potential of the secondary growth forest along the Abuan watershed at Ilagan, Isabela}

\section{Ginalyn S Pasamonte}

DOI: https://doi.org/10.22271/plants.2020.v8.i6a.1229

\section{Abstract}

The Abuan watershed had experienced deforestation due to illegal deforestation, poaching and land conversion. This has resulted to the loss of its ecosystem services. In the watershed area, restoration efforts showed encouraging results where secondary forest is flourishing. Secondary forest growth provides tremendous potential for large amounts of carbon sequestration.

This study aimed to determine the carbon sequestration potential of the secondary growth forest along Abuan watershed in Ilagan, Isabela. Specifically, it was conducted to identify the tree species present in the area and estimate the amount of carbon sequestered annually by the above ground carbon cover of the trees in the study area. Ten (10) sampling points measuring $20 \mathrm{~m}$ x $20 \mathrm{~m}$ were established using Point center quarter method (PCQM). Tree census was conducted and identification was done up to its species level. The amount of carbon sequestered by the trees was measured.

Twenty six (26) species was documented. The above ground carbon by the trees in the watershed is calculated at $18,452 \mathrm{~kg}$. The species Shorea concorta (White lauan) has the highest amount of carbon sequestered while Dipterocarpus validus (Hagakhak) species sequestered the lowest. The age, height and DBH are directly proportional to the amount of carbon sequestration. Thus, the younger the tree, the higher the amount of carbon sequestered and the older the tree, the lower the amount of carbon sequestration. In addition, the taller and wider the tree, the higher carbon sequestration potential per year. It is recommended that below ground potential including the carbon-sink function of the soil be included in estimating the carbon sequestration potential of the secondary growth forest to understand fully this ecosystem function.

Keywords: Carbon sequestration, carbon sequestration potential, secondary growth forest

\section{Introduction}

Terrestrial ecosystem plays a key role in climate change as they may act both as a source or sink for carbon dioxide (Trexler and Haugen, 1994) ${ }^{[8]}$. Deforestation has resulted in about one third of the rise of $\mathrm{CO} 2$ in the atmosphere. Mature and particularly old forest contain large store of carbon that gets locked up in the live and dead wood for long period of time (IPCC, 2000) ${ }^{[2]}$. This carbon is released into atmosphere due to deforestation thereby acting as a source for carbon emission. On the other hand plant sequesters carbon during photosynthesis, which is the elemental base for carbon (C) accumulation, growth, and biomass production of plants. Photosynthetic responses to rising global mean temperature of terrestrial plants can

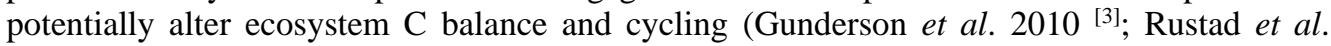
2001 ${ }^{[6]}$. Forest not only sustains its own carbon but also has the potential to absorb carbon from the atmosphere. Reduction of photosynthesizing biomass through indiscriminate deforestation constitutes damage to the self-regulating mechanism that removes carbon dioxide from the atmosphere combustion. Global emissions of carbon have been increasing for about 140 years since the beginning of the Industrial Revolution. The sharpest increase is observed during the most recent 50 years, principally from accelerated use of fossil fuels. Concentration of carbon dioxide in the atmosphere has increased by about $25 \%$ from pre-industrial levels and will approach 360 ppm by end of year 2000 (Tomson and Jensel, 2002). It is estimated that future doubling of atmospheric $\mathrm{Co}_{2}$ concentration to about $700 \mathrm{ppm}$ will risk an accompanying greenhouse rise of approximately $1.5-4.0^{\circ} \mathrm{C}$ in mean global surface temperature.

Trees remove carbon dioxide from the atmosphere through the natural process of photosynthesis and store the carbon $(\mathrm{C})$ in their leaves, branches, stems, bark and roots. 
They convert carbon dioxide into sugar, cellulose and other carbon containing compounds that they use for growth and development. Approximately half the dry weight of a tree's biomass is carbon. They are effective at capturing particulate pollution from the air and also help lower concentrations of other air pollutants. Trees help reduce excess runoff and water pollution by capturing and filtering storm water. Trees are unique in their ability to lock up large amounts of carbon in their wood, and continue to add carbon as they grow (Shin et al., 2007) ${ }^{[7]}$.

According to De Witt (2004), trees in the forest, at an age of 10-30 years old, can sequester carbon at a maximum rate. At age 30 years, about 200 to 520 tons $\mathrm{CO}_{2}$ are sequestered per hectare in forests with productivity ranging from low to high. After this age, if the trees are not harvested, the sequestration rate slows gradually until maturity at about 80 to $100+$ years of age, and flattens out from then on as growth is balanced by decay.

Due of deforestation, the Abuan watershed has lost its ecosystem services, one of which is the sequestration of carbon. Recognizing the role of watersheds in maintain the integrity of the ecosystem, both the government and nongovernment agencies in partnership with the communities along the watershed area planted trees in an attempt to restore forest cover. Hence, the study was conducted to determine the above ground carbon sequestration potential of the secondary growth forest along the Abuan watershed in Ilagan, Isabela.

\section{Materials and Methods \\ Description of the Study Area}

The study area lies within the western buffer zone of the Northern Sierra Madre Natural Park (Fig 1). It is located at the Midwest of the province of Isabela $\left(17^{\circ} 11^{\prime} 12^{\prime}\right.$ 'N, $122^{\circ} 7^{\prime}$ 12 "E). The land area consists of an approximate 63, 754 hectares that supports the livelihoods of some 2900 farming households. The lower sub-catchments consist of farm lands, residual forests and brush lands with an area of 19,000 hectares (or $31 \%$ ) of the watershed area.

The soil in most areas in the watershed is known as mountain soil. The rolling areas has loam soil while the hilly region are characterized sandy loam soils. The upper catchments are predominantly forest $(89 \%)$ with more than 56,000 hectares. Agricultural crops (4.4 percent) are planted in the lower sub catchments of almost 3000 hectares. Such agricultural crops are mostly planted with maize. Kaingin or Swiden farming with a total area of 287.5 hectares are in patches within the watershed.

The watershed is named after the Abuan River, which, together with the smaller Bintacan River, drains into the Pinacanauan de Ilagan River, before merging with the Cagayan River.

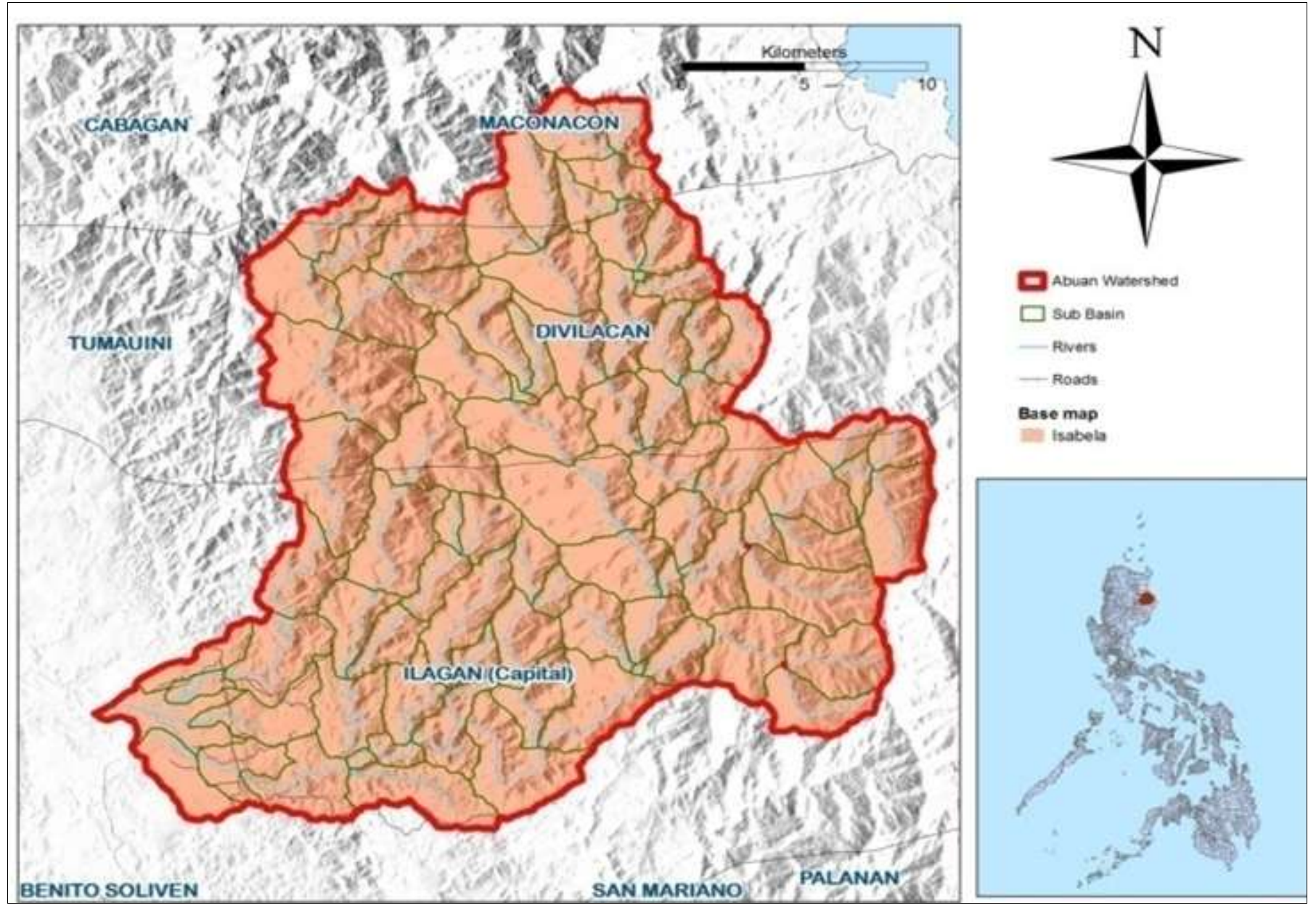

Fig 1: Map of the Abuan watershed.

\section{Sampling Methods}

The point center quarter method was used in establishing the sampling points for the study. The layout of a $20 \times 20 \mathrm{~m}$ each plot is shown diagrammatically in Figure 2. Ten (10) plots were established in the study area. An arbitrary straight line through the S-N direction measuring $400 \mathrm{~m}$ was laid. Sampling points were established every $20 \mathrm{~m}$ with a $20 \mathrm{~m}$ interval between sampling points. 


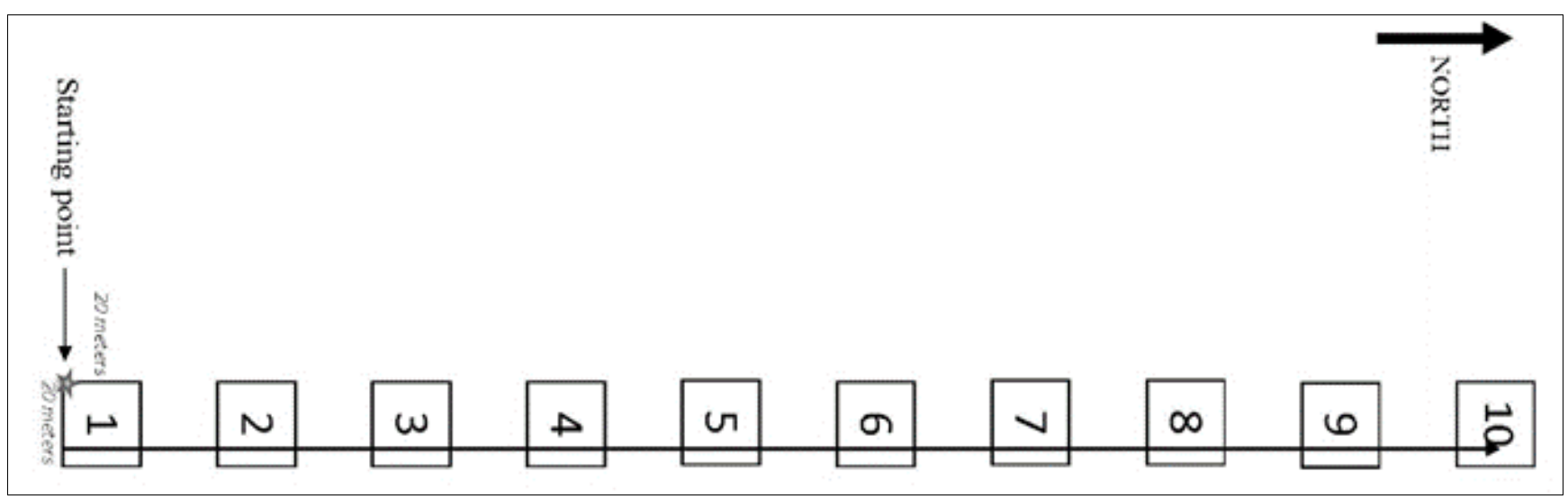

Fig 1: Layout of the study area in the Abuan watershed.

\section{Tree Census and Tree Tagging}

All free standing woody stems with a diameter at breast height (at $1.3 \mathrm{~m})$ of $\geq 5 \mathrm{~cm}$ are included in the census. Saplings and vines were not included in the census. Tags made of aluminum are attached to all trees (and stems, for branching trees) that are included in the census. The label includes the quadrat number and the tree number. The tags are attached with a copper wire/nylon (for small stems), or nailed to the tree (for big stems). The diameter of the tree is measured at $1.3 \mathrm{~m}$ from the ground, using the diameter tape. For big trees, an improvised caliper was used. Tree caliper was used for small diameter trees. The measurement is then recorded on the data sheet.

\section{Species Identification}

Trees were identified up to its species level. Identification is made based on dried voucher specimens collected from the field. Photo-documentation of trees used was also done and used to facilitate identification. Dichotomous key for identification was utilized. Literature and on-line resources were also used to validate identification.

\section{Data Gathered}

Calculation of the Amount of $\mathrm{CO}_{2}$ Sequestered in a tree was calculated following Raison and Myers (1992) ${ }^{[5]}$, and Attiwill et al. (1994) ${ }^{[1]}$ as follows:

1. The total (green) weight (w) of the tree was determined as follows:

for trees with $\mathrm{DBH}<11 ; \mathrm{W}=0.25 \mathrm{D}^{2} \mathrm{H}$

for trees with $\mathrm{DBH}>11 ; \mathrm{W}=0.15 \mathrm{D}^{2} \mathrm{H}$

2. where: $\mathrm{W}$ is the Above-ground weight of the tree in pounds;

$\mathrm{DBH}$ is the diameter at breast height;

$\mathrm{H}$ is the height of the tree

3. The dry weight of the tree was derived using the following constants recommended by the University of Nebraska (2002):

dry weight of the tree = weight of the tree $\mathrm{x} 72.5 \%$

4. where: dry matter accounts to $72.5 \%$ while moisture of the trees is $27.5 \%$

5. The weight of carbon in the tree. The average carbon content is generally $50 \%$ of the tree's total volume. Hence, weight of carbon in the tree was determined by multiplying the dry weight of the tree by $50 \%$.

6. The weight of carbon dioxide sequestered in the tree was determined by multiplying the weight of carbon in the tree by 3.6663 . The value of 3.6663 was obtained by computing for the molecular weight of $\mathrm{CO}_{2}$. The atomic weight of Carbon is 12.001115. The atomic weight of Oxygen is 15.9994. The weight of $\mathrm{CO}_{2}$ is $\mathrm{C}+2 * \mathrm{O}=$ 43.999915. The ratio of $\mathrm{CO}_{2}$ to $\mathrm{C}$ is $43.999915 / 12.001115=3.6663$.

7. The weight of $\mathrm{CO}_{2}$ sequestered in the tree per year was calculated by dividing the weight of carbon dioxide sequestered in the tree by the estimated age of the tree.

\section{Results and Discussions}

Tree Species Composition of the Abuan Watershed

There were 26 tree species documented. Of the 26 tree species, twenty five (25) species belonged to class Magnoliopsida. These species are Pipturus argenteus (Agandong) of family Vebenaceae, Dipterocarpus grandiflorus (Apitong) of family Dipterocarpaceae, Homalanthus populneus, (Balanti) of family Juglandaceae, Fenilleae dulcis (Dulawen) of family Anacardiceae, Dipterocarpus validus (Hagakhak) of family Dipterocarpaceae, Laucaena leucocephala (Ipil Ipil) of family Fabaceae, Coffea Arabica (Kape) of family Rubiaceae, Wringtia pubescens (Lanite) of family Apocynaceae, Palaquim philippense (Malak malak) of family Sapotaceae, Dracontomelon edule (Manaring) of family Anacardiaceae, Ficus religiosa (Maragawid) of family Moraceae, Kleinhovia hospital (Marakapas) of family Malvaceae, Coffea africantes (Marakape) of family Ribiaceae, Shorea squamata (Mayapis) of family Dipterocarpaceae, Pterocarpus indicus (Narra) of family Fabaceae, Artocarpus camansi (Pakak) of family Annonaceae, Shorea negronensis (Red Lauan) of family Dipterocarpaceae, Macaranga tanarius (Samak) of family Euphorbiaceae, Sandoricum koetjape (Santol) of family Meliaceae, Shorea polysperma (Tanguile) of family Dipterocarpaceae, Ficus nota (Tibig) of family Anacardicaea, Schefflera actinophylla (Umbrella Tree) of family Araliaceae, Shorea concorta (White Lauan) of family Dipterocarpaceae, Antidesma bunius (Wild Bignay) of family Phyllanthaceae, and Nephelium lappaceum (Wild Rambutan) of family Sapindaceae. One (1) species belonged to class Liliopsida; the Saribus rotundifulius (Anahaw) of order Arecales presented in Table 1. 
Table 1: Trees Species Composition of the Forest Trees Community in Abuan Watershed.

\begin{tabular}{|c|c|c|c|c|}
\hline Class & Order & Family & Species & Common Name \\
\hline \multirow[t]{25}{*}{ Magnoliopsida } & Vebenales & Vebenaceae & Pipturus argenteus & Agandong \\
\hline & Malvales & Dipterocarpaceae & Dipterocarpus grandiflorus & Apitong \\
\hline & Malpighiales & Juglandaceae & Homalanthus populneus & Balanti \\
\hline & Sapindales & Anacardiceae & Fenilleae dulcis & Dulawen \\
\hline & Malvales & Dipterocarpaceae & Dipterocarpus validus & Hagakhak \\
\hline & Fabales & Fabaceae & Laucaena leucocephala & Ipil-ipil \\
\hline & Gentianales & Rubiaceae & Coffea arabica & Kape \\
\hline & Gentianales & Apocynaceae & Wringtia pubescens & Lanite \\
\hline & Ericales & Sapotaceae & Palaquim philippense & Malak-malak \\
\hline & Sapindales & Anacardiaceae & Dracontomelon edule & Manaring \\
\hline & Rosales & Moraceae & Ficus religiosa & Maragawid \\
\hline & Malvales & Malvaceae & Kleinhovia hospita & Marakapas \\
\hline & Gentianales & Ribiaceae & Coffea africantes & Marakape \\
\hline & Malvales & Dipterocarpaceae & Shorea squamata & Mayapis \\
\hline & Fabales & Fabaceae & Pterocarpus indicus & Narra \\
\hline & Rosales & Annonaceae & Artocarpus camansi & Pakak \\
\hline & Malvales & Dipterocarpaceae & Shorea negronensis & Red Lauan \\
\hline & Malpighiales & Euphorbiaceae & Macaranga tanarius & Samak \\
\hline & Sapindales & Meliaceae & Sandoricum koetjape & Santol \\
\hline & Malvales & Dipterocarpaceae & Shorea polysperma & Tanguile \\
\hline & Sapindales & Anacardiceae & Ficus nota & Tibig \\
\hline & Apiales & Araliaceae & Schefflera actinophylla & Umbrella Tree \\
\hline & Malvales & Dipterocarpaceae & Shorea concorta & White Lauan \\
\hline & Malpighiales & Phyllanthaceae & Antidesma bunius & Wild Bignay \\
\hline & Sapindales & Sapindaceae & Nephelium lappaceum & Wild Rambutan \\
\hline Liliopsida & Arecales & Aracaceae & Saribus rotundifulius & Anahaw \\
\hline
\end{tabular}

\section{Above-Ground Carbon Sequestration Potential of the Tree Species in Abuan Watershed}

A total of $144,464 \mathrm{~kg}$ was computed as the total sequestered carbon and $18,452 \mathrm{~kg}$ sequestered carbon per year by all of the tree species in the ten (10) plots in Abuan Watershed (Table 2). Plot 5 got the highest carbon sequestered with a twenty $27,072 \mathrm{~kg}$ and the lowest sequestered carbon was found in plot 10 having $3,527 \mathrm{~kg}$.

Table 2: Above - Ground Carbon sequestration potential of the tree species in Abuan watershed.

\begin{tabular}{|c|c|c|c|c|c|}
\hline Plot & Total Weight $(\mathbf{k g})$ & Dry Weight $(\mathbf{k g})$ & Carbon Weight $(\mathbf{k g})$ & Sequestered Carbon Dioxide (kg) & Sequestered Carbon Dioxide per Year (kg) \\
\hline 1 & 7015 & 5086 & 2543 & 9323 & 2603 \\
\hline 2 & 12142 & 8803 & 4402 & 16138 & 2146 \\
\hline 3 & 5418 & 3928 & 1964 & 7200 & 1457 \\
\hline 4 & 4791 & 3474 & 1737 & 6368 & 1925 \\
\hline 5 & 20369 & 14768 & 7384 & 27072 & 1847 \\
\hline 6 & 15919 & 11541 & 5770 & 21156 & 2137 \\
\hline 7 & 11535 & 8363 & 4182 & 15331 & 1642 \\
\hline 8 & 16642 & 12066 & 6033 & 22118 & 2272 \\
\hline 9 & 12213 & 8854 & 4427 & 16231 & 433 \\
\hline 10 & 2654 & 1924 & 962 & 3527 & 18452 \\
\hline Total & 108699 & 78807 & 39403 & 144464 & \\
\hline
\end{tabular}

The Individual carbon sequestration of the tree species was shown in Table 4. It was found out that Shorea concorta (White Lauan) species sequestered the highest amount of carbon having $13,524 \mathrm{~kg}$ and Dipterocarpus validus (Hagakhak) species sequestered the lowest amount of carbon with $1,954 \mathrm{~kg}$. Moreover, the carbon sequestration per year by the individual tree species can be affected by age of the trees. Species Ficus nota (Tibig) sequestered the highest amount of carbon per year with $963 \mathrm{~kg}$ and Dipterocarpus grandiflorus (Apitong) sequestered the lowest amount of carbon per year with $91 \mathrm{~kg}$.

Result shows that age, height and $\mathrm{DBH}$ are directly proportional to the amount of carbon sequestration. Thus, the younger the tree, the higher the amount of carbom dequestered and the older the tree, the lower the amount of carbon sequestration. In addition, the taller and wider the tree, the higher carbon sequestration potential per year. Many studies has already been conducted to understand the carbon sequestration potential of forest trees. In the study of Juwarkar et al. (2011) ${ }^{[4]}$ in India, they have found out that Tectona grandis showed the highest tree diameter of $26 \mathrm{~cm}$ and average height of $19.85 \mathrm{~m}$ while the lowest tree diameter and height of $10.35 \mathrm{~cm}$ and $8.25 \mathrm{~m}$ was shown by Ziziphus glaberrima, respectively. The claimed further that the total above and belowground biomass of the trees in the natural forest of Tadoba Andhari Tiger Reserve were observed to be $178.09 \mathrm{Mg} / \mathrm{ha}$ and $46.30 \mathrm{Mg} / \mathrm{ha}$ respectively. They also found out that the the carbon stock accumulated in vegetation was found to be $112.19 \mathrm{MgC} / \mathrm{ha}$.

Terakunpisut et al. (2016) also conducted a study on carbon sequestration potential in aboveground biomass of Thong Pha Phum National Forest, Thailand. They found out that carbon sequestration among varied different types of forests. Tropical rain forest had higher carbon stock than dry evergreen forest and mixed deciduous forest with $137.73 \pm 48.07,70.29 \pm 7.38$ and $48.14 \pm 16.72$ ton $\mathrm{C} /$ ha, respectively. The $\geq 4.5-20 \mathrm{~cm}$ trees potentially provided a greater carbon sequestration in tropical rain forest and dry evergreen forest while the size of 
$>20-40 \mathrm{~cm}$ gave potentially high carbon sequestration in mixed deciduous forest. In conclusion, the greatest carbon sequestration potential is in mixed deciduous forest followed by tropical rain forest and dry evergreen forest in Thong Pha Phum National Forest. This evidence indicates the potential for growth to reach the climax stage of succession in the near future. These smaller trees do not have the highest carbon sequestration potential but they are relevant in terms of their future potential to grow up.

Table 4: List of tree species with the highest carbon sequestration in Abuan watershed.

\begin{tabular}{|c|c|c|c|c|c|}
\hline Species & Age (yr) & $\begin{array}{c}\text { Plant height } \\
\text { (ft) }\end{array}$ & $\begin{array}{l}\text { Diameter } \\
\text { (in) }\end{array}$ & $\begin{array}{c}\text { Sequestered carbon dioxide } \\
(\mathrm{kg})\end{array}$ & $\begin{array}{c}\text { Sequestered carbon dioxide per } \\
\text { year }(\mathrm{kg})\end{array}$ \\
\hline Laucaena leucocephala - Ipil Ipil & 5 & 30 & 38 & 3927 & 785 \\
\hline Dracontomelon edule - Manaring & 20 & 75 & 20 & 2714 & 316 \\
\hline Dipterocarpus grandiflorus - Apitong & 23 & 65 & 19 & 2084 & 91 \\
\hline Dipterocarpus validus -Hagakhak & 10 & 50 & 21 & 1954 & 195 \\
\hline Shorea concorta - White Lauan & 35 & 120 & 35 & 13524 & 386 \\
\hline Shorea concorta - White Lauan & 30 & 120 & 23 & 5617 & 187 \\
\hline Ficus nota - Tibig & 7 & 36 & 46 & 6617 & 963 \\
\hline Shorea squamata - Mayapis & 25 & 95 & 20 & 5957 & 238 \\
\hline Shorea concorta - White Lauan & 10 & 90 & 23 & 4212 & 421 \\
\hline Dipterocarpus grandiflorus - Apitong & 13 & 95 & 15 & 2011 & 154 \\
\hline
\end{tabular}

\section{Conclusion}

There were 26 taxa documented consisting of 26 tree species; 25 species belonged to class Magnoliopsida and nne (1) species belonged to class Liliopsida. The most abundant tree species in the area was Macaranga tanarius (samak tree) with a total population of 68. This was followed by Shorea concorta (White Lauan) and Dipterocarpus grandiflorus (Apitong) and Nephelium lappaceum (Wild Rambutan) with a population of 46 and 16 , respectively.

A total of $144,464 \mathrm{~kg}$ was computed as the total sequestered carbon and $18,452 \mathrm{~kg}$ sequestered carbon per year by all of the tree species in the ten (10) plots in Abuan Watershed. Plot 5 got the highest carbon sequestered with a twenty $27,072 \mathrm{~kg}$ and the lowest sequestered carbon was found in plot 10 having $3,527 \mathrm{~kg}$. It was found out that Shorea concorta (White Lauan) species sequestered the highest amount of carbon having 13,524 kg and Dipterocarpus validus (Hagakhak) species sequestered the lowest amount of carbon with $1,954 \mathrm{~kg}$. Moreover, the carbon sequestration per year by the individual tree species can be affected by age of the trees. Species Ficus nota (Tibig) sequestered the highest amount of carbon per year with $963 \mathrm{~kg}$ and Dipterocarpus grandiflorus (Apitong) sequestered the lowest amount of carbon per year with $91 \mathrm{~kg}$.

Moreover, it can be deduced from the foregoing result of the study that the above-ground biomass of the secondary growth forest along the Abuan watershed has the potential to serve as a carbon sink due to its carbon sequestration activity. It can also be concluded that age, height and DBH are directly proportional to the amount of carbon sequestration. Thus, the younger the tree, the higher the amount of carbom dequestered and the older the tree, the lower the amount of carbon sequestration. In addition, the taller and wider the tree, the higher carbon sequestration potential per year.

The carbon sequestration potential of the above-ground biomass of the secondary forest along Abuan watershed. Hence it is recommended that below ground potential including the carbon-sink function of the soil be included in estimating the carbon sequestration potential of the secondary growth forest to understand fully this ecosystem function.

\section{References}

1. Attiwill PM. Nutrient cycling in a eucalyptus oblique forest. growth, biomass and net primary productivity. Aust. J Bot 1994;27:439-458.
2. IPCC. UN Intergovernmental Panel on Climate Change. Cambridge University Press, Cambridge, UK 2000.

3. Gunderson CA, O'Hara KH, Campion CM, Walker AV, Edwards NT. Thermal plasticity of photosynthesis: the role of acclimation in forest responses to a warming climate. Glob. Change Biol 2010;16:2272-2286.

4. Juwarkar A, Varghese AAO, Singh SK, Aher VV, Thawale PR. Carbon sequestration potential in aboveground biomass of natural reserve forest of Central India. International Journal of Agriculture: Research and Review 2011;1(2):80-86. Retrieved at http://www.ecisi.com on January 25, 2016.

5. Raison RJ, Myers BJ. The biology of forest growth experiment: linking water and nitrogen availability to the growth of Pinus radiata. Ecology and Management, New York 1992.

6. Rustad LE, Campbell J, Marion GM, Norby RJ, Mitchell MJ, Hartley AE et al. A meta-analysis of the response of soil respiration, net $\mathrm{N}$ mineralization, and aboveground plant growth to experimental ecosystem warming. Oecologia 2001;126:543-56.

7. Shin MY, Miah MD, Lee KH. Potential contribution of the forestry sector in Bangladesh to carbon sequestration. J Environ. Manag 2007;82(2;):260-276.

8. Trexler MC, Haugen C. Keeping it green: evaluating tropical forestry strategies to mitigate global warming. World Resources Institute, Washington DC. WRI 1994, 52. 